\section{Thermal Death Kinetics of Some Common Postharvest Pathogens of Papaya}

\author{
Harvey T. Chan, Jr., Kate A. Nishijima, Myles H. Taniguchi, and \\ Edward S. Linse \\ U.S. Department of Agriculture, Agricultural Research Service, Tropical \\ Fruit and Vegetable Research Laboratory, P.O. Box 4459, Hilo, HI 96720
}

Additional index words. Carica papaya, Colletotrichum gloeosporiodes, Guignardia, Enterobacter cloacae, Stemphylium lycopersici, Rhizopus stolonifer, Monilinia fructicola, heat treatment, quarantine treatment, ACC oxidase, decimal reduction times, Oriental fruit flies

\begin{abstract}
Thermal death kinetics, decimal reduction times (D-values), and rate constants, $\mathrm{k}$, at 43 to $49{ }^{\circ} \mathrm{C}$ were determined for spore or cell suspensions of Colletotrichum gloeosporiodes (Penz.) Penz. \& Sacc. in Penz., Guignardia psidii Ullasa \& Rawl, Guignardia sp. Viala \& Ravaz., and Enterobacter cloacae (Jordan) Hormaeche \& Edwards. D-values for Monilinia fructicola (Wint.) Honey, Rhizopus stolonifer (Ehr. : Fr.) Vuill., and Stemphylium lycopersici (Enjoji) Yamamoto were calculated and extrapolated from published reports. We compared the relative heat resistances of the various postharvest pathogens to their expected survival during quarantine heat treatments and found that Guignardia, Rhizopus, and $E$. cloacae could be expected to survive quarantine heat treatments.
\end{abstract}

Heat treatments have played an important role in the disinfestation of disease and insect pests in fresh fruit for many years (Armstrong, 1994; Couey, 1989). A hot water treatment at $49^{\circ} \mathrm{C}$ for 20 min to control postharvest decay in papayas (Carica papaya L.) was used commercially in Hawaii for more than 30 years following fumigation with ethylene dibromide (Akamine and Arisumi, 1953) and is currently used in some packinghouses after vapor heat treatment. Hot water treatment of $30 \mathrm{~min}$ at 42 ${ }^{\circ} \mathrm{C}$ followed by $20 \mathrm{~min}$ at $49{ }^{\circ} \mathrm{C}$ (Couey and Hayes, 1986) or hot air treatments with $40 \%$ to $60 \%$ relative humidity at $48.5{ }^{\circ} \mathrm{C}$ for $3.5 \mathrm{~h}$ (Armstrong et al., 1995) have been used to disinfest Tephritid fruit flies from papayas. The role of heat in insect and fruit systems have been studied in thermal death kinetics of fruit flies (Jang, 1986; Moss and Chan, 1993) and in thermal inactivation kinetics of fruit ripening enzyme systems, i.e., polygalacturonase (Chan et al., 1981) and 1aminocyclopropane-1-carboxylate oxidase (ACC oxidase) (Chan, 1986, 1991).

Numerical simulation models integrating thermal diffusion in papayas with temperature stress on a ripening enzyme and on survival of fruit flies have been reported (Laidlaw and Hayes, 1990). However, information on the thermal sensitivity of postharvest fungal spores

Received for publication 30 Oct. 1995. Accepted for publication 8 Apr. 1996. Mention of a trademark or proprietary product is for identification only and does not imply a guarantee or warranty of the product by the U.S. Dept. of Agriculture. The cost of publishing this paper was defrayed in part by the payment of page charges. Under postal regulations, this paper therefore must be hereby marked advertisement solely to indicate this fact. and hyphae is lacking (Coates and Johnson, 1993). For example, postharvest quarantine hot air and hot water treatments either reduce or enhance anthracnose (Colletotrichum gloeosporioides), Guignardia spot(Guignardia sp.), and internal yellowing (Enterobactercloacae) diseases of papaya (Alvarez and Nishijima, 1987; Nishijima et al., 1987, 1992), but thermal death kinetics of the pathogens are unreported. This study reports the thermal death kinetics of some postharvest pathogens of papaya to provide insight into the role of heat treatments in control of postharvest diseases.

\section{Materials and Methods}

Fungal cultures. Colletotrichum identified by K. Nishijima in 1986 and Guignardia sp. (Phyllosticta caricaecola Saw. anamorph) (papaya strain) (KN 7-14-88, IMI 366584 ) cultures were obtained in 1988 , both from single conidia isolations from diseased papaya fruit collected on the Island of Hawaii. Guignardia psidii (guava strain) (KN 12-894, IMI 366585) cultures were obtained in 1994 from single conidia isolations from diseased guava (Psidium guajava L.) fruit collected in Hawaii (Island of Hawaii). Guignardia strains were identified by the International Mycological Institute Biosystematics Services (United Kingdom). All cultures were grown on potato dextrose agar (PDA; Difco Laboratories, Detroit) in continuous fluorescent light (Sylvania Daylight, 15W; Osram-Sylvania Co., Westfield, Ind.) at $24^{\circ} \mathrm{C}$ for 12 to 14 days and stored as stock cultures in sterile distilled water (SDW) tubes.

Procedures. Thermal death studies were performed on $C$. gloeosporioides and two gloeosporioides cultures were obtained and strains of Guignardia spp. using the flask method of Hatcher et al. (1979). Conidia or mycelial plugs were removed from the surface of C. gloeosporioides or Guignardia cultures, respectively, and suspended in $15 \mathrm{~mL}$ SDW, and filtered through sterile stainless steel screens $(30-\mu \mathrm{m}$ pore size $)$ to remove hyphae. Conidia concentrations were determined using a hemacytometer. For Guignardia spp., ascospores accounted for $<5 \%$ of total spores. Spore suspensions were mixed and diluted to $10^{5}$ to $10^{6}$ spores $/ \mathrm{mL}$.

For the heat treatments, $36 \mathrm{~mL}$ of SDW (pH 5.3 to 5.5) contained in a $100-\mathrm{mL}$ beaker was heated with a constant-temperature circulator (PolyScience, Niles, Ill.) in a water bath. A sterile stainless steel propeller was used to circulate the heated water in the beaker. When the desired temperature in the beaker was reached $\left(43,45,46,47\right.$, or $\left.49^{\circ} \mathrm{C}\right), 4 \mathrm{~mL}$ of the spore suspension was pipetted into the beaker and the timer set. Water bath temperatures were typically set at 0.7 to $1.0^{\circ} \mathrm{C}$ higher than the desired temperatures in the beaker to attain the desired beaker temperatures. Beaker water temperature was monitored with thermocouples connected to a data logger (Omnidata Polycorder; Omnidata Intl., Logan, Utah). After a designated time interval (0 to $60 \mathrm{~min}$ for $C$. gloeosporiodes or 0 to $180 \mathrm{~min}$ for Guignardia strain), $0.5 \mathrm{~mL}$ of heated spore suspension was withdrawn from the beaker and mixed into $1.5 \mathrm{~mL}$ of cool $\left(8\right.$ to $\left.10{ }^{\circ} \mathrm{C}\right)$ SDW in tubes held in a cold water bath. After the tube contents had reached $<20^{\circ} \mathrm{C}$ ( 2 to 3 min in cold water bath), the tube was removed and held at room temperature for viability assay.

Viability was assayed by mixing the contents of the test tube on a vortex mixer, withdrawing $0.2 \mathrm{~mL}$ from each tube of various time-temperature treatments, and pipetting onto PDA medium. The spores were spread over the agar surface with a sterile, bent glass rod and the agar plates were allowed to air-dry in the laminar airflow hood. Plates were inverted and incubated at $24^{\circ} \mathrm{C}$; germinated and nongerminated conidia were counted under a $20 \times$ objective of a light microscope (Bausch \& Lomb, Rochester, N.Y.) after 18 to $24 \mathrm{~h}$ and again at $48 \mathrm{~h}$ to include "delayed" germination. Each temperature represented separate tests and each test was replicated at least twice. Percent germination was based on the mean of two counts of 100 spores each from plates incubated $48 \mathrm{~h}$.

For the control sample, $1.0 \mathrm{~mL}$ of filtered spore inoculum was pipetted into $9 \mathrm{~mL}$ SDW and mixed with a vortex mixer. From this tube, $0.5 \mathrm{~mL}$ was pipetted and mixed into a tube containing $1.5 \mathrm{~mL}$ SDW precooled in cold water bath $\left(8\right.$ to $\left.10^{\circ} \mathrm{C}\right)$. After $\approx 2 \mathrm{~min}$, the tube in the cold water bath was removed and mixed, then $0.2 \mathrm{~mL}$ of the tube contents was pipetted onto a PDA plate and spread over the agar surface with a sterile bent glass rod. For $C$. gloeosporioides, "0" time (control sample) counts were only counted at $18 \mathrm{~h}$ because hyphae were overgrown after that period.

Thermal death kinetics for the fungi Stemphylium lycopersici (Glazner et al., 1984), 
Rhizopus stolonifer, and Monilinia fructicola (Smith and Blomquist, 1970) were calculated from the literature. Data for M. fructicola and $R$. stolonifer were limited to two or three data points; thus, the reliability and precision of these extracted data are uncertain. These studies were included in this report to illustrate the potential use of thermal death kinetics in determining the efficacy of vapor heat treatments (VHT) and hot water treatments for the control of fungal pathogens.

Bacterial cultures. The Enterobacter cloacae strains PV-5 and WT-2, obtained in 1986 (Nishijima et al., 1987) from diseased papaya fruits (PV-5) and hot water treatment tanks (WT-2) (collected before and after heat treatments), were used for thermal death studies. The cultures were maintained on yeastdextrose-calcium carbonate agar (YDC) at 30 ${ }^{\circ} \mathrm{C}$. A water bath (Haake E-2, Berlin, Germany) containing test tubes $(12 \times 75 \mathrm{~mm})$ in a test tube rack were equilibrated to 45 or $49^{\circ} \mathrm{C}$. Temperatures were monitored with a YSI telethermometer (model 42 SC; Yellow Springs Instrument Co., Yellow Springs, Ohio) equipped with a temperature probe placed in a test tube containing $1.0 \mathrm{~mL}$ of SDW. Aliquots $(0.1 \mathrm{~mL})$ of a standard bacterial suspension $\left[\approx 10^{8}\right.$ colony-forming units $\left.(\mathrm{cfu}) / \mathrm{mL}\right]$ prepared from a 24-h YDC culture were pipetted (in triplicate) into preheated tubes containing 0.9 $\mathrm{mL}$ SDW. After measured intervals of 0,15 , 30,60 , and $120 \mathrm{~min}$, the tubes were removed from the bath and cooled in ice water for $30 \mathrm{sec}$ to $<20^{\circ} \mathrm{C}$ before diluting and plating. Survival of bacterial populations were determined by counting the number of colonies visible on nutrient agar plates after $24 \mathrm{~h}$ incubation at 30 ${ }^{\circ} \mathrm{C}$. Data were reported as percent survival relative to "0 time" (control) colony counts. Each test was done three times and consisted of running one bacterial strain at a single temperature.

Data calculations and equations. Procedures for calculations and equations that were applied in our kinetic studies are as follows:

For those organisms that followed logarithmic death, a first-order rate equation of

$\frac{\mathrm{dN}}{\mathrm{dt}}=-\mathrm{kN}$

was applied. Rearranging and integrating Eq. [1] results in:

$\int \frac{\mathrm{dN}}{\mathrm{N}}=-\mathrm{k} \int \mathrm{dt}$

subsequently, integrating this equation results in:

$\log \mathrm{N}=-\mathrm{kt} / 2.303+\log \mathrm{N}_{0}+\log \mathrm{C}$

When Eq. [2] is integrated between the limits, $\mathrm{N}_{1}$ at $\mathrm{t}_{1}$ and $\mathrm{N}_{2}$ at $\mathrm{t}_{2}$, it results in:

$\int_{\mathrm{N}_{1}}^{\mathrm{N}_{2}} \frac{\mathrm{dN}}{\mathrm{N}}=-\mathrm{k} \int_{\mathrm{t}_{1}}^{\mathrm{t}_{2}} \mathrm{dt}$

in which $\mathrm{N}_{1}=$ number of organisms at time $\mathrm{t}_{1}$, $\mathrm{N}_{2}=$ number of organisms at $\mathrm{t}_{2}$. If $\mathrm{N}_{1}=\mathrm{N}_{0}$ (initial number of organisms) at $\mathrm{t}_{1}=0$, and $\mathrm{N}$
$=$ number of surviving organisms at $\mathrm{t}$, the resulting integrated Eq. [4] results in the firstorder rate equation (Kittsley, 1955; Stumbo, 1973):

$\log \mathrm{N}=-\mathrm{kt} / 2.303+\log \mathrm{N}_{0}$

Eq. [5]

The above equations were used in the following manner: Eq. [3] was applied to the thermal death data of all organisms to screen for fitness to a first-order logarithmic decay model using least squares fitting of the equation (Table Curve 2D V2.0; AISN Software; Jandel Scientific, San Rafael, Calif.), which also reported the $R^{2}$ values for each curve. The criterion employed was that $\mathrm{N}_{0}$ must approximate the value 100 because survival data were expressed in percentages that would require $\mathrm{N}_{0} \cong 100$. When this criterion was met, then Eq. [5] was applied to calculate rate constants, $\mathrm{k}$, and D-values. When $\mathrm{N}_{0}$ values were several magnitudes $>100$, we concluded that the thermal death curves were nonlogarithmic, with potential for an extensive lag phase. However, in certain cases, we found that at $>46{ }^{\circ} \mathrm{C}$, the lag phase becomes minimal and thermal death kinetics approached the classical first-order models, in which case the first-order models were applied. However, at $<46{ }^{\circ} \mathrm{C}$, where extensive lag phases were evident, other equations, such as that of King et al. (1979) or Pruitt and Kamau (1993), which describe nonlogarithmic thermal death, were more appropriate and therefore applied.

The equation derived by King et al. (1979):

$\left(\log \mathrm{N}_{0}-\log \mathrm{N}\right)^{\mathrm{a}}=\mathrm{kt}+\mathrm{c}$

was used when there was sufficient data to calculate the nonlogarithmic thermal death rate constant, $\underline{\mathrm{k}}$, where $\mathrm{N}_{0}$ and $\mathrm{N}$ are the original and surviving number of spores after heat treatment and the time in minutes. The exponential constant a was determined from the reciprocal of the slope of a least squares best fit of the $\log$ survival $\left[\log \left(\log \mathrm{N}_{0}-\log \mathrm{N}\right)\right.$ ] against $\log$ time. The a value of the least severe treatment showing mortality of at least $10 \%$ was used to determine the subsequent $\underline{\mathrm{c}}$ and $\underline{\mathrm{k}}$ values at the more severe temperatures. The rate constant $\underline{\mathrm{k}}$ was determined from the slope of the best fit line of a plot of $\left(\log \mathrm{N}_{0}-\log \mathrm{N}\right)^{\mathrm{a}}$ vs. time. Use of an iterative method further improved the value of the constants, resulting in a closer approximation to the data and a smaller variance (Jang, 1986). The a value determined by Jang's (1986) method was then used to calculate new $\underline{\mathrm{c}}$ and $\underline{\mathrm{k}}$ values for each temperature. Iterative fitting was done using Table Curve 2D V2.0 using a LevenburgMarquardt algorithm for the least square fitting and reported $R^{2}$ values for fitted curves.

Decimal reduction time (D-values) represent the time required to attain $90 \%$ death at a certain temperature and is a convenient way of comparing heat resistance. D-values are calculated from the rate constant, $\mathrm{k}$, where:

$\mathrm{D}=2.303 / \mathrm{k}$

and $\mathrm{D}$ is the time required for the survival curve to traverse one log cycle. For example, if 1-D represents $90 \%$ kill, then 2-D would be
99\% kill, 3-D would be $99.9 \%$ kill (Stumbo, 1973).

In cases where the specific data points were not available, rate constants (k) were calculated using the Arrhenius equation (Kittsley, 1955):

$\mathrm{E}_{\mathrm{a}}=\frac{2.303 \mathrm{RT}_{2} \mathrm{~T}_{1}}{\left(\mathrm{~T}_{1}-\mathrm{T}_{2}\right)} \log \frac{\mathrm{k}_{2}}{\mathrm{k}_{1}}$

where $\mathrm{E}_{\mathrm{a}}=$ energy of activation, $\mathrm{R}=8.314$ $\mathrm{J} \cdot$ degree $^{-1} \cdot \mathrm{mol}^{-1}, \mathrm{k}_{1}$ and $\mathrm{k}_{2}$ are the rate constants at the absolute temperatures $\mathrm{T}_{1}$ and $\mathrm{T}_{2}$, respectively.

\section{Results and Discussion}

Effects of time and temperature on the survival of C. gloeosporioides (Fig. 1A), Guignardia sp. (papaya) (Fig. 1B), and $G$. psidii (guava) (Fig. 1C) on semilogarithmic plots showed nonlinear kinetics for all three organisms. Therefore, a nonexponential model of death kinetics (Eq. [6]) was applied. Using the equation of King et al. (1979) the data produced high correlation coefficients (Table 1). From the thermal death rate constants, the energy of activation $\mathrm{E}_{\mathrm{a}}$ was calculated (Table 1). $\mathrm{E}_{\mathrm{a}}$ values for $C$. gloeosporiodes and the two species of Guignardia were very close, indicating that similar death rates would be expected from increases in temperature. Based on the D-values (Table 1), the relative heat resistance was $G$. psidii > Guignardia sp.>C. gloeosporioides. Interestingly, the fungal pathogens with the highest heat resistance, the two strains of Guignardia, also required heat to activate germination, since for Guignardia sp. (papaya) (Fig. 1B) and G. psidii (guava) (Fig. 1C) a thermal activation phase was evident. Spore germination increased in the early stages of heating at 43 to $49^{\circ} \mathrm{C}$ before thermal death set in. Thermal kinetics were calculated only for the death phases and not for the activation phases of Guignardia. The heat of activation for spore germination and heat resistance phenomena correlated with the observation that Guignardia rarely occur on papaya except when papaya are treated too long during quarantine heat treatments at 48 to $49{ }^{\circ} \mathrm{C}$ (Alvarez and Nishijima, 1987). Since the activation phenomenon complicates the interpretation of thermal death kinetics for Guignardia, other thermodynamic models need to be considered or developed.

For the survival of $R$. stolonifer and $M$. fructicola, Eqs. [3] and [5] were applied and the resulting survival curve for each respective organism was then analyzed for linearity $\left(\mathrm{N}_{0} \cong 100 \%\right.$ ) (Table 2). High $\mathrm{N}_{0}$ values were obtained for: Monilinia-dormant and -germinated at $43{ }^{\circ} \mathrm{C}$, and Rhizopus-dormant at 46 ${ }^{\circ} \mathrm{C}$. However, as the temperature increased, linearity of survival increased for $R$. stolonifer and M. fructicola, in which case Eq. [3] was applied. Equation [3] also was more appropriate than Eq. [6] in the case of Monilinia and Rhizopus because of the meager data given. High D-values at $43^{\circ} \mathrm{C}$ for Monilinia and at 46 ${ }^{\circ} \mathrm{C}$ for Rhizopus-dormant indicated that attempts to control postharvest decay at these 

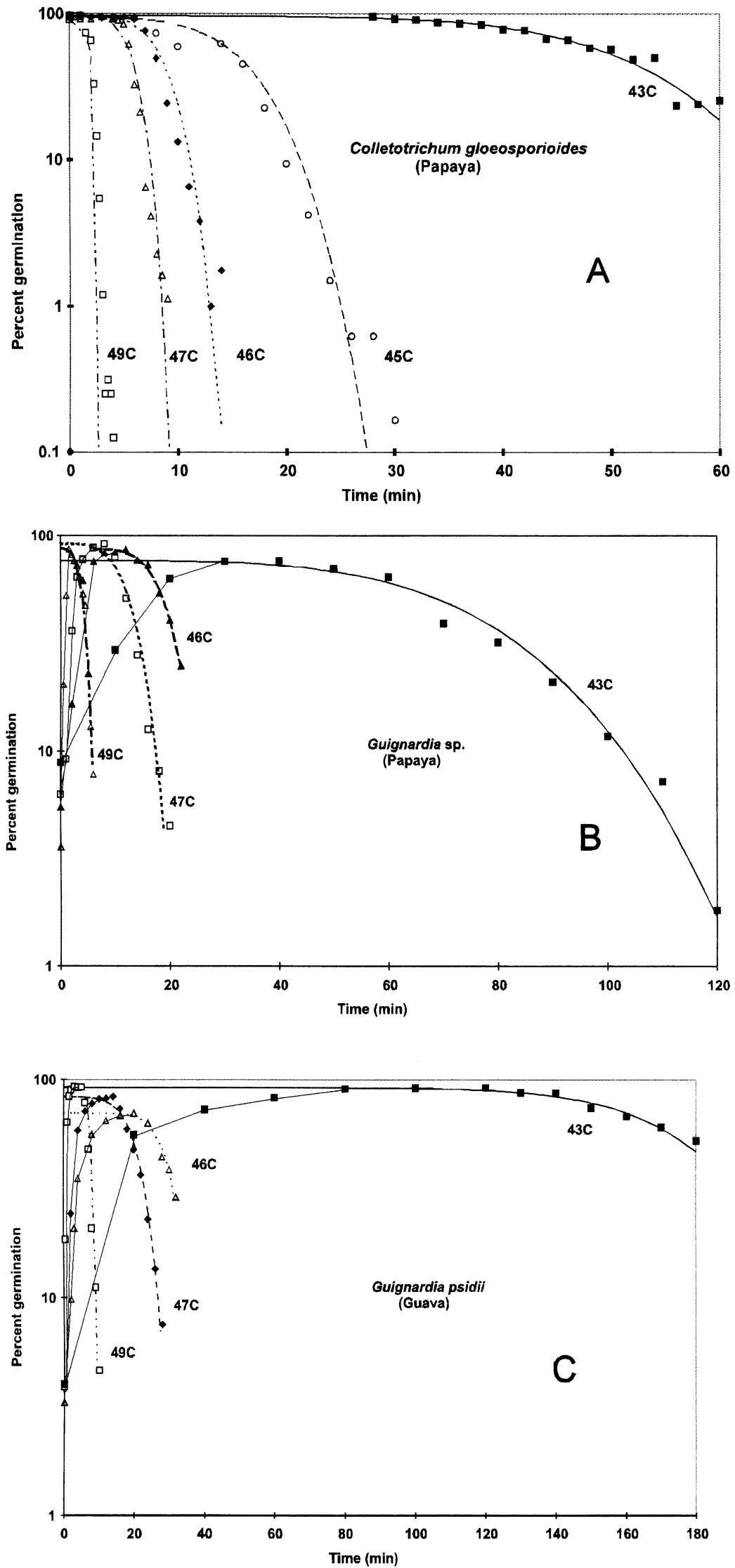

Fig. 1. Thermal death plots using King's equation (Eq. [6]) for (A) Colletotrichum gloeosporiodes, (B) Guignardia sp. (papaya), and (C) G. psidii (guava) in distilled water at pH 5.3-5.5. Curve fitting for (BC) Guignardia sp. and G. psidii was done only for the death phase and not for the activation phase. Results are the means of at least three tests in which percent germination in each test was based on the mean of two counts of 100 spores each from PDA plates incubated at $24{ }^{\circ} \mathrm{C}$ for $48 \mathrm{~h}$. temperatures could be problematic. Another organism that appears to be highly heat resistant is the bacterium Enterobacter cloacae (Zhu et al., 1986). Enterobacter cloacae causes internal yellowing and the infection site is in the internal seed cavity and surrounding tissue of papayas (Nishijima et al., 1987; Tang et al., 1972). Under the present quarantine (VHT) regime, the internal temperatures of papayas are required to reach $47.2{ }^{\circ} \mathrm{C}$ after which the fruit are hydrocooled (Armstrong et al., 1989). D-values for E. cloacae at 45 and $49^{\circ} \mathrm{C}$ (Table 3 ) indicated potential survival of E. cloacae during the VHT, since the internal cavity of papayas was $<60 \mathrm{~min}$ at the critical thermal death temperatures (i.e., $>45^{\circ} \mathrm{C}$ ) (Armstrong et al., 1995).

In contrast to E. cloacae, most of the postharvest fungal pathogens, including Rhizopus sp., were initially surface infectants exposed to the maximum severity $\left(48.5^{\circ} \mathrm{C}\right)$ of the quarantine temperature regime. Rhizopus stolonifer is one of the most destructive postharvest pathogens of papaya treated in hot water (Alvarez and Nishijima, 1987). The very long D-values of dormant spores of $R$. stolonifer, as calculated from data of Smith and Blomquist (1970) (>1400 min at $46^{\circ} \mathrm{C}$ ), were indicative of the heat resistance of these spores (Table 2) and may provide a rationale for the occasional ineffectiveness of heat treatments in controlling postharvest decay due to $R$. stolonifer. This heat resistance of dormant spores emphasized the importance of sanitation in the control of Rhizopus rot. Poor sanitation before quarantine treatment that allows the proliferation of inoculum, including dormant spores, could reduce the effectiveness of VHT and hot water quarantine treatments as a postharvest decay control method.

A comparison of the relative heat sensitivity for various life stages of the Oriental fruit fly expressed as 5-D (Jang, 1986), the dormant spores of $R$. stolonifer, the bacterial pathogen (E. cloacae) and the fruit ripening enzyme, ACC oxidase (Chan, 1986, 1991), expressed as 1-D-values (90\% kill) is appropriate (Fig. 2 ). The 5 -D values indicate that $99.999 \%$ is the expected kill range for Oriental fruit flies under probit 9 quarantine protocol. At $43^{\circ} \mathrm{C}$, the egg stage is more heat resistant than the first- and third-instar larval stages, while at 46 ${ }^{\circ} \mathrm{C}$ the larval stages are more heat resistant than the egg stages (Jang, 1986). The relationship between the heat sensitivity of the bacterial pathogen, E. cloacae, the fungal pathogen, $R$. stolonifer, and the disinfestation of larval stages of the Oriental fruit fly are important at 46 and $47^{\circ} \mathrm{C}$, which are typical temperatures encountered during quarantine VHT. At $46^{\circ} \mathrm{C}$ and $40 \mathrm{~min}$, death at 5-decimal reduction (5D) is attained for third-instar larvae of Oriental fruit fly, while death at 1-D is attained for $E$. cloacae, PV-5, indicating a possible $10 \%$ survival of E. cloacae. The survival of E. cloacae (papaya strain PV-5) was confirmed by a packinghouse survey that reported up to $9.7 \%$ internal yellowing disease in hot-water-treated papayas and recovery of E. cloacae from hot water treatment tanks (water tank strain WT2) (Nishijima et al., 1987). A 1-D value of 
Table 1. Decimal reduction times (D-values), rate constants (k), and coefficients of determination $\left(R^{2}\right)$, for Colletotrichum gloeosporiodes, Guignardia sp. from papaya, and for $G$. psidii from guava, derived from King et al. (1979) where $\left(\log \mathrm{N}_{0}-\log \mathrm{N}\right)^{\mathrm{a}}=\mathrm{kt}+\mathrm{C}$, in which $\mathrm{N}_{0}$ and $\mathrm{N}$ are the original and surviving number of spores and $\mathrm{t}=$ time in minutes and $\mathrm{a}=$ exponential constant .

\begin{tabular}{|c|c|c|c|c|c|c|c|}
\hline Fungus & $\begin{array}{c}\mathrm{t} \\
(\mathrm{C})\end{array}$ & $\begin{array}{c}\mathrm{k} \\
\left(\mathrm{min}^{-1}\right)\end{array}$ & $R^{2}$ & $\begin{array}{c}1-\mathrm{D} \\
(\mathrm{min})\end{array}$ & $\begin{array}{c}3-\mathrm{D} \\
(\mathrm{min})\end{array}$ & $a^{y}$ & $\begin{array}{c}\mathrm{E}_{\mathrm{a}}^{\mathrm{z}} \\
\left(\mathrm{kJ} \cdot \mathrm{mol}^{-1}\right)\end{array}$ \\
\hline \multirow[t]{5}{*}{ C. gloeosporiodes } & 43 & 0.0155 & 0.98 & 63.8 & 77.8 & 0.1781 & 447 \\
\hline & 45 & 0.0355 & 0.91 & 21.4 & 27.5 & & \\
\hline & 46 & 0.0721 & 0.93 & 11.2 & 14.2 & & \\
\hline & 47 & 0.1154 & 0.89 & 7.5 & 9.4 & & \\
\hline & 49 & 0.3620 & 0.91 & 2.9 & 3.5 & & \\
\hline \multirow[t]{4}{*}{ Guignardia sp. } & 43 & 0.0091 & 0.97 & 110 & 143 & 0.2385 & 394 \\
\hline & 46 & 0.0491 & 0.98 & 20.4 & 26.5 & & \\
\hline & 47 & 0.0537 & 0.93 & 18.6 & 24.2 & & \\
\hline & 49 & 0.1504 & 0.98 & 6.6 & 8.6 & & \\
\hline \multirow[t]{4}{*}{ G. psidii } & 43 & 0.0047 & 0.94 & 213 & 244 & 0.1250 & 418 \\
\hline & 46 & 0.0258 & 0.97 & 38.8 & 44.5 & & \\
\hline & 47 & 0.0248 & 0.98 & 40.3 & 46.3 & & \\
\hline & 49 & 0.1026 & 0.92 & 9.8 & 11.2 & & \\
\hline
\end{tabular}

${ }^{2} \mathrm{E}_{\mathrm{a}}=$ energy of activation.

${ }^{\mathrm{y}} \mathrm{a}=$ exponential constant.

Table 2. Thermal death constants (k), 1-D-values ( $\mathrm{min}$ ), and estimated original or percentage of population, $\mathrm{N}_{0}$ at heating time, $\mathrm{t}=0$, calculated from published data for spores of various postharvest pathogens.

\begin{tabular}{|c|c|c|c|c|}
\hline $\begin{array}{l}\text { Temp } \\
\left({ }^{\circ} \mathrm{C}\right)\end{array}$ & Organism & $\begin{array}{c}\text { D-value } \\
\text { (min) }\end{array}$ & $\begin{array}{c}\mathrm{k} \\
\left(\mathrm{min}^{-1}\right)\end{array}$ & $\begin{array}{l}\mathrm{N}_{0} \\
(\%)\end{array}$ \\
\hline \multirow[t]{3}{*}{43} & Monilinia $^{2}$ - dormant & $1865^{x}$ & 0.001 & 1250 \\
\hline & Monilinia - germinated & $1436^{x}$ & 0.002 & 8870 \\
\hline & Rhizopus $^{2}$ - germinated & $0.58^{\mathrm{w}}$ & 3.97 & 82.1 \\
\hline \multirow[t]{4}{*}{46} & Stemphylium $^{y}$ & $17.3^{\mathrm{w}}$ & 0.133 & 74.4 \\
\hline & Monilinia - germinated & $44.7^{\mathrm{w}}$ & 0.520 & 161.3 \\
\hline & Rhizopus - dormant & $1422^{x}$ & 0.002 & 5589 \\
\hline & Rhizopus - germinated & $0.26^{\mathrm{w}}$ & 8.96 & 86.5 \\
\hline 48 & Stemphylium & $8.65^{\mathrm{w}}$ & 0.266 & 99.2 \\
\hline \multirow[t]{3}{*}{49} & Monilinia - dormant & $1.73^{\mathrm{w}}$ & 1.33 & 109 \\
\hline & Rhizopus - dormant & $2.39^{\mathrm{w}}$ & 0.96 & 101 \\
\hline & Rhizopus - germinated & $0.33^{\mathrm{w}}$ & 7.03 & 90.9 \\
\hline 50 & Stemphylium & $8.46^{\mathrm{w}}$ & 0.272 & 99.9 \\
\hline \multirow[t]{3}{*}{52} & Monilinia - dormant & $0.84^{\mathrm{w}}$ & 2.74 & 97.3 \\
\hline & Rhizopus - dormant & $19.05^{\mathrm{w}}$ & 0.120 & 365 \\
\hline & Rhizopus - germinated & $0.40^{\mathrm{w}}$ & 5.73 & 94.4 \\
\hline 54 & Stemphylium & $0.58^{\mathrm{w}}$ & 3.98 & 99.4 \\
\hline
\end{tabular}

${ }^{2}$ Data for Monilinia fructicola and Rhizopus stolonifer from Smith and Blomquist (1970).

'Data for Stemphylium lycopersici from Glazener et al. (1984).

${ }^{x} \mathrm{D}$-values were derived from the formula, $\log \mathrm{N}=-\mathrm{kt} / 2.303+\log \mathrm{N}_{0}+\log \mathrm{C}$, based on the large $\mathrm{N}_{0}$ value following nonlinear death.

${ }^{\mathrm{w}} \mathrm{D}$-values were derived from $\mathrm{k}, \log \mathrm{N}=-\mathrm{kt} / 2.303+\log \mathrm{N}_{0}$.

$1422 \mathrm{~min}$ at $46^{\circ} \mathrm{C}$ and $600 \mathrm{~min}$ at $47^{\circ} \mathrm{C}$ for dormant spores of the fungal pathogen, $R$. stolonifer, indicates potential survival of this pathogen during and after postharvest vaporheat treatments since most treatments range from 270 to $360 \mathrm{~min}$ (Armstrong, 1994).

The long D-values for dormant spores of $R$. stolonifer indicate that any efforts to completely eradicate this pathogen with more severe heat treatments would disrupt normal fruit ripening by reducing ACC oxidase activity, a fruit-ripening enzyme (Chan, 1986). Thus, alternative postharvest decay control strategies (such as fungicides or biological control) for Rhizopus rot may be necessary.

In the case of the nonlogarithmic thermal death curves due to the existence of an extensive lag phase, especially at $<46{ }^{\circ} \mathrm{C}$, effective kill did not begin until the lag phase was complete. The death rate increased dramatically at higher temperatures where the lag phase of death was shorter (Fig. 1). Thus, heat treatment regimes programmed by temperature ramping or profiling should be designed to incorporate control of postharvest patho- gens and disinfestation of insects while maintaining fruit quality.

\section{Literature Cited}

Akamine, E.K. and T. Arisumi. 1953. Control of postharvest storage decay of fruits of papaya (Carica papaya $\mathrm{L}$.) with special reference to the effect of hot water. Proc. Amer. Soc. Hort. Sci. 61:270-274.

Alvarez, A.M. and W.T. Nishijima. 1987. Postharvest diseases of papaya. Plant Dis. 71:681-686.

Armstrong, J.W. 1994. Heat and cold treatments, p. 103-119. In: R.E. Paull and J.W. Armstrong (eds.). Insect pests and fresh horticultural products: Treatments and responses. CAB Intl., Wallingford, U.K.

Armstrong, J.W., J.D. Hansen, B. K-S. Hu, and S.A. Brown. 1989. High-temperature, forced-airquarantine treatment for papayas infested with Tephritid fruit flies (Diptera: Tephritidae). J. Econ. Entomol. 82:1667-1674

Armstrong, J.W., B.K-S. Hu, and S.A. Brown. 1995. Single-temperature forced hot-air quarantine treatment to control fruit flies (Dipetera: Tephritidae) in papaya. J. Econ. Entomol. 88:678-682.
Table 3. 1-D-values (min) and thermal death rate constant $(\mathrm{k})$ derived from the first-order kinetic equation (Eq. [5]), $\log \mathrm{N}=-\mathrm{kt} / 2.303+\log \mathrm{N}_{0}$, where $\mathrm{N}_{0}$ and $\mathrm{N}$ are the original and surviving numbers, respectively, of two strains of the internal yellowing bacterium, Enterobactercloacae, strain PV-5 from papaya fruit and strain WT-2 from hot water treatment tanks.

\begin{tabular}{llcc}
\hline $\begin{array}{l}\text { Temp } \\
\left({ }^{\circ} \mathrm{C}\right)\end{array}$ & Strain & $\begin{array}{c}\text { D-value } \\
(\mathrm{min})\end{array}$ & $\begin{array}{c}\mathrm{k} \\
\left(\mathrm{min}^{-1}\right)\end{array}$ \\
\hline 45 & PV-5 & 63.56 & 0.036 \\
& WT-2 & 35.30 & 0.065 \\
$46^{2}$ & PV-5 & 40.93 & 0.056 \\
& WT-2 & 26.92 & 0.086 \\
$47.2^{\mathrm{z}}$ & PV-5 & 24.14 & 0.095 \\
& WT-2 & 19.45 & 0.118 \\
49 & PV-5 & 10.93 & 0.211 \\
& WT-2 & 11.94 & 0.193 \\
\hline
\end{tabular}

${ }^{2} \mathrm{D}$ and $\mathrm{k}$ values for these temperatures were calculated from an Arrhenius plot using the energy of activation, $\mathrm{E}_{\mathrm{a}}$, derived from thermal death data at 45 and $49^{\circ} \mathrm{C}$

Chan, H.T., Jr. 1986. Effects of heat treatments on the ethylene-forming enzyme system in papayas. J. Food Sci. 51:581-583.

Chan, H.T., Jr. 1991. Ripeness and tissue depth effects on heat inactivation of papaya ethyleneforming enzyme. J. Food Sci. 56:996-998.

Chan, H.T., Jr., S.Y-T. Tam, and S.T. Seo. 1981. Papaya polygalacturonase and its role in thermally injured ripening fruit. J. Food Sci. 46:190191, 197.

Coates, L.M. and G.I. Johnson. 1993. Effective disease control in heat-disinfested fruit. Postharvest News \& Information 4(1):35N-40N .

Couey, H.M. 1989. Heat treatment for control of postharvest diseases and insect pests of fruits. HortScience 24:198-202.

Couey, H.M. and C.F. Hayes. 1986. Quarantine procedure for Hawaiian papaya using fruit selection and a two-stage hot water immersion. J. Econ. Entomol. 79:1307-1314.

Glazener, J.A., H.M. Couey, and A. Alvarez. 1984. Effect of postharvest treatments on Stemphylium rot of papaya. Plant Dis. 68:986-988.

Hatcher, W.S., J.L. Weihe, D.I. Murdock, J.F Folinazzo, E.C. Hill, and L.G. Albrigo. 1979. Growth requirements and thermal resistance of fungi belonging to the genus Byssochlamys. J. Food Sci. 44:118-122.

Jang, E.B. 1986. Kinetics of thermal death in eggs and first instars of three species of fruit flies (Diptera:Tephritidae) J.Econ. Entomol. 79:700705 .

King, A.D., H.G. Bayne, and G. Alderton. 1979. Nonlogarithmic death rate calculations for Byssochlamys fuloa and other micro-organisms. Appl. Environ. Microbiol. 37:596-600.

Kittsley, S.L. 1955. Physical chemistry. Barnes \& Noble, New York. p. 99-101.

Laidlaw, W.G. and C.G. Hayes. 1990. Calculation of ethylene-forming enzyme activity in papayas treated for control of Oriental fruit flies (Diptera: Tephritidae). J. Econ. Entomol. 83:1944-1948.

Moss, J.I. and H. T. Chan, Jr. 1993. Thermal death kinetics of Caribbean fruit fly (Diptera: Tephritidae) embryos. J. Econ. Entomol. 86:1162-1166.

Nishijima, K.A., H.M. Couey, and A.M. Alvarez. 1987. Internal yellowing, a bacterial disease of papaya fruits caused by Enterobacter cloacae. Plant Dis. 71:1029-1034.

Nishijima, K.A., C.K. Miura, J.W. Armstrong, S.A. Brown, and B.K-S. Hu. 1992. Effect of forced, hot-air treatment of papaya fruit on fruit quality and incidence of postharvest diseases. Plant Dis. 76:723-727. 


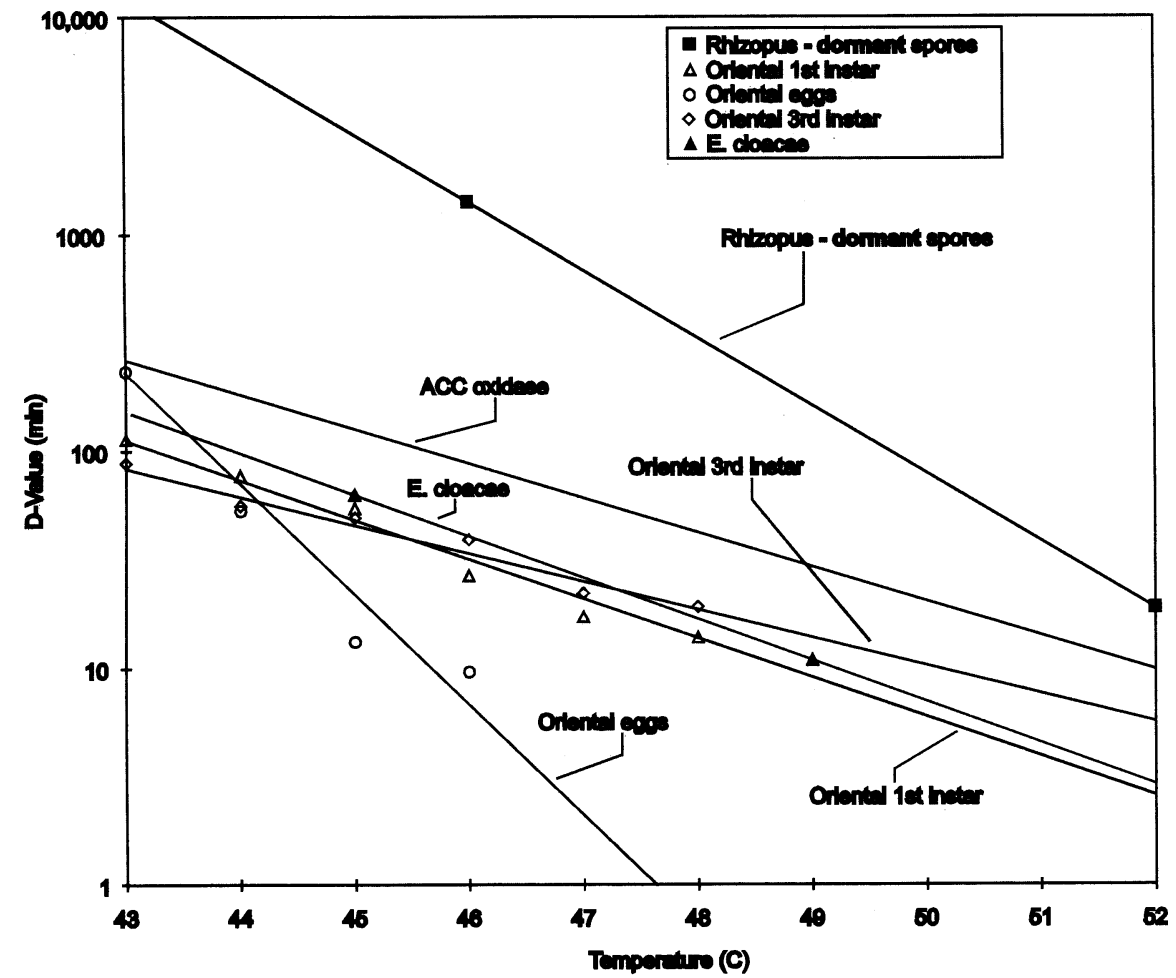

Fig. 2. Effects of temperature on 5-D values of Oriental fruit fly eggs; first and third instar larvae (Jang, 1986); and 1-D values for papaya ACC oxidase (EFE) (Chan, 1991), Rhizopus stolonifer dormant spores (Smith and Blomquist, 1970), and Enterobacter cloacae, PV-5.
Pruitt, K. M. and D. N. Kamau. 1993. Mathmatical models of bacterial growth, inhibition and death under combined stress conditions. J. Industrial Microbiol. 12:221-231.

Smith, W.L. and M. Blomquist. 1970. Thermolability of dormant and germinated Monilinia fructicola and Rhizopus stolonifer spores. Phytopathology 60:866-868.

Stumbo, C.R. 1973. Thermobacteriology in food processing. Academic, New York. p. 70-92.

Tang, C.S., K. Bhothipaksa, and H.A. Frank. 1972. Bacterial degradation of benzylisothiocyanate. Applied Micro. 23:1145-1148.

Zhu, J-B., Z-G. Li, L-W. Wang, S-S. Shen, and S-C. Shen. 1986. Temperature sensitivity of a nif Alike gene in Enterobacter cloacae. J. Bacteriol. 166:357-359. 